\title{
A Comparative Study of CLIL Trajectories in the Polish Education System
}

\begin{abstract}
This paper aims to present a comparative study of the existing curricular Content and Language Integrated Learning (CLIL) models as used by teachers in Polish lower- and uppersecondary schools in the system of education which ended in 2017 when the New Education Reform was implemented. The article reveals the details pertaining to general language education in Poland and bilingual classrooms focusing on CLIL. The main goal is to analyse which languages are most frequently employed in bilingual education as the medium of instruction, the school subjects whose content is imparted through the medium of a foreign language as well as the four major curricular models developed and implemented for the needs of bilingual provision in Poland.
\end{abstract}

Keywords: bilingualism; bilingual education; CLIL; language teaching; secondary schools

\section{Primerjalna študija oblik CLIL-a v poljskem izobraževalnem sistemu}

\section{POVZETEK}

Prispevek predstavlja primerjalno študijo obstoječih učnih modelov pristopa CLIL, ki so jih uporabljali poljski učitelji v nižjih in višjih srednješolskih sistemih pred Novo izobraževalno reformo leta 2017. Avtor se v članku osredotoči na splošno tujejezikovno izobraževanje na Poljskem in na dvojezične šole, ki uporabljajo pristop CLIL. Glavni cilj prispevka je ugotoviti, kateri jeziki se najpogosteje uporabljajo v dvojezičnih programih kot učni jeziki in kateri predmeti se poučujejo v tujem jeziku, ter opisati štiri vodilne kurikularne modele, ki so se razvili za potrebe dvojezičnega pouka na Poljskem.

Ključne besede: dvojezičnost; dvojezično izobraževanje; CLIL; učenje jezikov; srednje šole 


\section{Language Education in Poland}

Poland's transition to democracy led to the end of the Communist system in 1989. The transformations that occurred after 1989 triggered not only socio-economic changes, but also laid the foundations for changes in education in Poland. The present study is based on the system of education which was initiated with the Education Reform of 1999. Its main assumptions resulted from, among others, the Act of 8 January 1999. The aim of this parliamentary act was to implement changes to improve the overall level of Polish education. A comprehensive primary school cycle of six years was introduced, to be followed by a lower-secondary school of three years and three- or four-year secondary schools (general upper-secondary or technical schools). The New Reform enacted by the Government in 2017 redrew the existing school system adjusted to other EU member states by implementing radical changes and re-establishing the two-tier education system that had existed prior to 1999. This reform was implemented at the beginning of the $2017 / 2018$ school year, and it aimed to reinvigorate vocational schooling. The key element of the "old-new" two-level system was eliminating three-year lower-secondary schools and extending the primary school cycle by two years to eight in total, and the secondary school cycle by one year to four and five years. Within both the new structure (after 2017) and old one (1999-2017) English has always been one of the most popular foreign languages taught in Poland. This might be surprising, as due to historical influences the languages that were traditionally popular in Poland were Russian and German. However, after 1989, when Poland became a democratic country, and especially after 2004, when it joined the European Union, the Polish education system started to favour English as the main foreign language (Górowska-Fells 2012).

\section{Bilingual Education in Poland}

While bilingual education in Poland is not a new phenomenon, it should be noted that no uniform methodology has been implemented successfully yet. The reasons are twofold. First of all, as observed by Baetens-Beardsmore (1993), educational traditions in a particular country determine whether certain subjects are to be taught by the medium of a foreign language. Secondly, these are the prevailing linguistic needs that dictate the most desirable provision. As rightly posited by Wolff and Otwinowska-Kasztelanic (2010) and Romanowski (2018b), approaches to Content and Language Integrated Learning (CLIL) vary in specific EU states as a result of administrative decisions taken by governments. Depending on the educational context while implementing CLIL, such factors as the choice of content subjects, the proportion of CLIL and non-CLIL classes, the recruitment process, or the type of school in which CLIL is introduced, are considered (Czura and Papaja 2013).

The first CLIL-related pedagogies were introduced in Poland as far back as the 1970s, when selected content subjects were taught through the medium of a foreign language for the whole duration of a lesson in a secondary school in Gdynia (Zielonka 2007; Papaja 2014). The language initially used was English. At the time this form of instruction was regarded as elitist, and in some environments it still is. Nowadays, a vast number of schools offer CLIL instruction using English, German, French, Spanish and Italian as the languages of 
instruction. Recently, there has also been an attempt to introduce Russian-medium class sections, although these proved very unpopular, and thus the project was dropped.

It must be underlined that CLIL provision in Polish schooling is labelled as bilingual education (Dzięgielewska 2008). Special sections are established in primary and secondary schools where learners undergo instruction in a selected foreign language as well as in their mother tongue. The instruction is usually limited to two, three or four subjects, most commonly maths, physics, chemistry, biology, geography, and history of art.

\section{Theoretical Underpinnings of Content and Language Integrated Learning (CLIL)}

Content and Language Integrated Learning (CLIL) is a commonly applied term describing the approaches when the teaching of content subjects is realized through the medium of a foreign language (Coyle, Hood, and Marsh 2010). Wolff $(2003,11)$ assumes that foreign languages are best learnt by focusing not so much on the language itself but on the transmitted content taken from school subjects, e.g. mathematics, geography, biology, physics, chemistry, etc. As such, from the very beginning CLIL referred to the promotion of innovative methods and, in particular, to the teaching of classes in a foreign language for disciplines other than languages, providing bilingual teaching. As indicated by Perez Cañado (2016), high hopes have been pinned on the potential of CLIL as a lever for change and success in the linguistic arena.

The CLIL methodological approach seeking to foster the integrated learning of languages and other areas of curricular content has been a fast-developing phenomenon in Europe. At the European level, interest is growing in the approach which, according to Mehisto, Marsh and Frigols (2014), brings many benefits to students.

Complementing the national profiles reported in the Eurydice survey, numerous teacherbased publications provide insights into how CLIL is being realized in more than 20 European countries (Maljers, Marsh, and Wolff 2007; Marsh and Wolff 2007; Dalton-Puffer 2011; Pérez Cañado 2014; Merino and Lasagabaster 2015). One important fact, common to all these studies, is the predominance of the English language. Over the past two decades an increasing body of research has demonstrated that CLIL can enhance multilingualism and provide opportunities for deepening learners' knowledge and skills. CLIL has been found to be additive (one language supporting the other) and not subtractive (one language working against the other). It involves a process which is generally curriculum-driven with the language curriculum arising from the content curriculum (Gierlinger 2017).

Following the same line of reasoning, it should be noted that CLIL has been very explicit about delineating that Learning involves the Integration of both Content and Language, i.e. learning of any content must involve the learning of the language associated with it (Romanowski 2018a). At the level of schooling, successful education in either a first or additional language requires from the learners to be equipped with the language for thinking about the content. When learning through CLIL, where an additional language is used, language-supportive resources, methods and activities are actively and coherently used to enable learners to make use of language purposefully. This support acts as a form of scaffolding helping learners to effectively 
process information, negotiate understanding, and co-construct knowledge (Mehisto, Marsh, and Frigols 2014; Anderson 2009; Dalton-Puffer 2017; Ruiz de Zarobe 2017).

Considering the fact that English has become, on the one hand, the language of science and academic research and, on the other, an obligatory subject in all schools, the most logical decision would be to combine the two conditions so that a learner could take advantage of them simultaneously (Romanowski 2016a). This is the core of CLIL, also labelled as a dual-focused educational approach in which an additional language is used for the learning and teaching of content and language, with the objective of promoting both content and language mastery to pre-defined levels (Marsh et al. 2010). It is essential to highlight that the additional language is not supposed to be the only medium of instruction, and thus it should be used interchangeably with the mother tongue. Its frequency of use will largely depend on the level of proficiency among teachers and students, as well as the complexity of the issues being discussed. That is why integrating language and non-language content has been referred to as the hallmark of all forms of bilingual education (Genesee 1987; Cenoz and Genesee 1998: 35-67; Lo and Macaro 2015).

All the approaches implemented in bilingual education in Polish schools originated from CLIL methodology. Four main types of instruction or curricular models are to be distinguished in schools (Marsh, Zając, and Gozdawa-Gołębiowska 2008; Romanowski 2016a). The distinctive feature lies in the amount of target language used versus the application of the mother tongue. In Extensive Language Medium Instruction (A), lessons are mainly conducted in a foreign language. The mother tongue is restricted to situations where translation of terminology is required, or short recapitulation of the main points is needed. This model is used to achieve the syllabus aims as well as to develop learners' language competence to a very high level. In Partial Language Medium Instruction (B), lessons are conducted in both Polish and a foreign language and the two languages are used interchangeably. About $50 \%$ of lesson time is devoted to each language. The predominant aim is to achieve course objectives, and less attention is paid to linguistic competence. The logic behind this model is that this will achieve the expected content learning outcomes while developing and using a very high degree of competence in the target language. Limited Language Medium Instruction (C) offers lessons with limited use of a foreign language, with between $10 \%$ and $50 \%$ of lesson time being devoted to it. Teaching the course content is the primary objective, while linguistic knowledge is expanded chiefly through the study of new lexis, in order to achieve the expected content learning outcomes alongside the limited use of the target language. Last but not least, when a foreign language is used only on particular occasions we opt for Specific Language Medium Instruction (D). With this, very little time is devoted to the foreign language, which is used to achieve particular aims (e.g. a lesson is conducted in Polish, but it is based on texts in the target language or project work where the results are presented in the target language, however most of the content studied earlier is available in Polish). This model is complementary as it focuses on the course objectives and the secondary aim involves the use and development of foreign language competence. The major objective is to complement courses taught in Polish and fulfil the expected content learning outcomes by providing opportunities for specific forms of the foreign language usage and development (Romanowski 2018b). 


\section{The Scale of Bilingual Education in Polish Lower- and Upper-Secondary Schools}

In a report published by the Centre for Education Development in Warsaw, Pawlak (2015) indicates that there are 180 lower-secondary schools in Poland with bilingual instruction educating almost 19,500 students. In comparison, it is noteworthy that the number of upper-secondary schools with bilingual instruction in Poland is around half as many - only 94 institutions with over 9,400 students.

TABLE 1. Schools with bilingual education.

\begin{tabular}{|c|c|c|c|c|}
\hline \multirow[t]{2}{*}{ Provinces } & \multicolumn{2}{|c|}{ Number of schools } & \multicolumn{2}{|c|}{ Number of students } \\
\hline & $\begin{array}{l}\text { Lower- } \\
\text { secondary }\end{array}$ & $\begin{array}{l}\text { Upper- } \\
\text { secondary }\end{array}$ & $\begin{array}{l}\text { Lower- } \\
\text { secondary }\end{array}$ & $\begin{array}{l}\text { Upper- } \\
\text { secondary }\end{array}$ \\
\hline Mazovian & 45 & 25 & 4,851 & 2,660 \\
\hline Silesian & 29 & 13 & 2,942 & 1,621 \\
\hline Lower Silesian & 21 & 6 & 2,066 & 503 \\
\hline Greater Poland & 16 & 8 & 2,026 & 894 \\
\hline Łódzkie & 13 & 6 & 1,085 & 478 \\
\hline Opole & 10 & 7 & 827 & 235 \\
\hline Lublin & 8 & 2 & 754 & 252 \\
\hline $\begin{array}{l}\text { Kuyavian- } \\
\text { Pomeranian }\end{array}$ & 8 & 4 & 691 & 435 \\
\hline Pomeranian & 7 & 10 & 752 & 1,077 \\
\hline Subcarpathian & 6 & 1 & 518 & 13 \\
\hline $\begin{array}{l}\text { Western } \\
\text { Pomeranian }\end{array}$ & 5 & 5 & 1,208 & 448 \\
\hline Lesser Poland & 4 & 3 & 434 & 499 \\
\hline Lubusz & 3 & 1 & 475 & 43 \\
\hline Podlasie & 3 & 2 & 313 & 119 \\
\hline $\begin{array}{l}\text { Warmian- } \\
\text { Masurian }\end{array}$ & 2 & 1 & 441 & 126 \\
\hline Świętokrzyskie & 0 & 0 & 0 & 0 \\
\hline Total & 180 & 94 & 19,383 & 9,403 \\
\hline
\end{tabular}

Bilingual instruction at lower- and upper-secondary levels takes place in all the Polish provinces except for one, namely Świętokrzyskie. The highest number of schools and students has been found in bigger cities, such as: Warsaw, Kraków, Katowice, Gdańsk, Poznań, Łódź and Wrocław. The most popular language used as a medium of instruction is English, present in $65 \%$ of the reported schools. German, performing the same role in 52 schools, seems to be the second most popular language if we consider the number of institutions; however, if 
our criterion changes to the number of students, it appears that French, with almost 4,000 students is the second leading foreign language offered in both types of schools. Spanish is less popular, and utilized in around 10\% of the schools with bilingual instruction. Italian and Russian are rare, as they are present in only five and four schools respectively, with the former being slightly more popular.

The geographical distribution of bilingual sections according to languages is also interesting. English is present in all the provinces whereas German is particularly popular in the western part of Poland (Western Pomerania, Lubusz, Lower Silesian, Silesian and Opole Provinces). In contrast, the instruction in Spanish and French is offered only in the biggest cities (Warsaw, Kraków, Poznań, Wrocław, Łódź). With the least popular languages, the following conclusion can be drawn: the less popular a language is, the more likely it is that it will be taught only in the provinces with the highest populations (Warsaw, Poznań, Kraków).

TABLE 2. Languages as the medium of instruction.

\begin{tabular}{|l|c|c|c|c|}
\hline \multirow{2}{*}{$\begin{array}{l}\text { Languages of } \\
\text { instruction }\end{array}$} & \multicolumn{2}{|c|}{ Number of schools } & \multicolumn{2}{c|}{ Number of students } \\
\cline { 2 - 5 } & $\begin{array}{c}\text { Lower- } \\
\text { secondary } \\
\text { schools }\end{array}$ & $\begin{array}{c}\text { Upper- } \\
\text { secondary } \\
\text { schools }\end{array}$ & $\begin{array}{c}\text { Lower- } \\
\text { secondary } \\
\text { schools }\end{array}$ & $\begin{array}{c}\text { Upper- } \\
\text { secondary } \\
\text { schools }\end{array}$ \\
\hline English & 134 & 56 & 12,789 & 5,144 \\
\hline German & 30 & 22 & 2,289 & 1,307 \\
\hline French & 23 & 12 & 2,655 & 1,278 \\
\hline Spanish & 18 & 15 & 1,431 & 1,511 \\
\hline Italian & 3 & 2 & 191 & 115 \\
\hline Russian & 2 & 2 & 28 & 48 \\
\hline Total & $210(180)$ & 109 & 19,383 & 9,403 \\
\hline
\end{tabular}

Analysing the data presented in both tables, we can see that in Mazovian Province there are 70 schools educating over 6,500 students, whereas in Greater Poland there are only 24 schools educating almost 3,000, and hence the number of schools is not necessarily in proportion to the number of students. On top of that, it needs to be emphasized that the density of schools in a particular province does not determine the total number of students involved in bilingual provision. As indicated earlier, there are schools which offer bilingual education in all the sections, however there are those institutions that decide specifically how many sections to launch each year where this type of provision will be available. In addition, there are schools where bilingual instruction is possible in one language only, in contrast to those institutions where two or three languages are used in parallel. There thus exists a discrepancy in the total number of lower-secondary schools (see Table 2).

\section{The Study}

The present study was conducted between September 2016 and March 2017. It is part of an ongoing research project devoted to bilingual programmes at the (lower- and upper-) 
secondary level of education in Poland. The intention was to focus on the teachers of content (non-linguistic) subjects involved in the teaching in bilingual classrooms and seek answers to the following questions:

1. How many subjects are taught in parallel? Do the numbers differ depending on the type of school (lower- or upper-secondary)?

2. Which subjects are taught through the medium of a foreign language? Do they vary depending on the type of school (lower- or upper-secondary)?

3. Which languages are used in lower- and upper-secondary schools as the medium of instruction?

4. Which curricular models are used by teachers of lower- and upper-secondary schools?

Altogether 203 teachers from 101 schools agreed to provide their responses to the outlined problems. There were 145 teachers from 62 lower-secondary schools and 58 teachers from 39 upper-secondary schools who participated in the survey.

TABLE 3. Participating teachers by each type of school.

\begin{tabular}{|l|l|c|c|c|}
\hline & \multicolumn{4}{l|}{$\begin{array}{l}\text { Number of participating } \\
\text { teachers N = 203 }\end{array}$} \\
\hline & $\begin{array}{l}\text { Number of teachers / } \\
\text { lower-secondary schools }\end{array}$ & $\%$ & $\begin{array}{c}\text { Number of teachers / } \\
\text { upper-secondary schools }\end{array}$ & $\%$ \\
\hline & 145 & & 58 & \\
\hline English & 76 & 52.5 & 27 & 46.5 \\
\hline German & 46 & 31.8 & 14 & 24.1 \\
\hline French & 13 & 8.9 & 9 & 15.5 \\
\hline Spanish & 10 & 6.8 & 7 & 12.2 \\
\hline Italian & 0 & 0 & 1 & 1.7 \\
\hline Russian & 0 & 0 & 0 & 0 \\
\hline
\end{tabular}

\subsection{The Frequency of Occurrence of Particular School Subjects in CLIL Provision}

The choice and number of taught subjects varies from country to country, and in most EU states it does not exceed two or three subjects (Iluk 2000; Dzięgielewska 2002; Romanowski 2016b). In Poland, however, up to four subjects are offered concurrently. In addition, exact sciences, such as mathematics, physics, chemistry and biology, are the most frequent choices in lower-secondary schools, whereas it is physics, chemistry and biology in the case of uppersecondary education. They are regarded as difficult courses in comparison to the humanities, such as geography, philosophy, or history, where instruction is also provided in a foreign language. Depending on the availability of qualified teachers, the intensity and language 
exposure may vary. In exceptional situations one subject in lower-secondary schools and two subjects in upper-secondary schools are taught every year, and hence the available subjects change from one year to another.

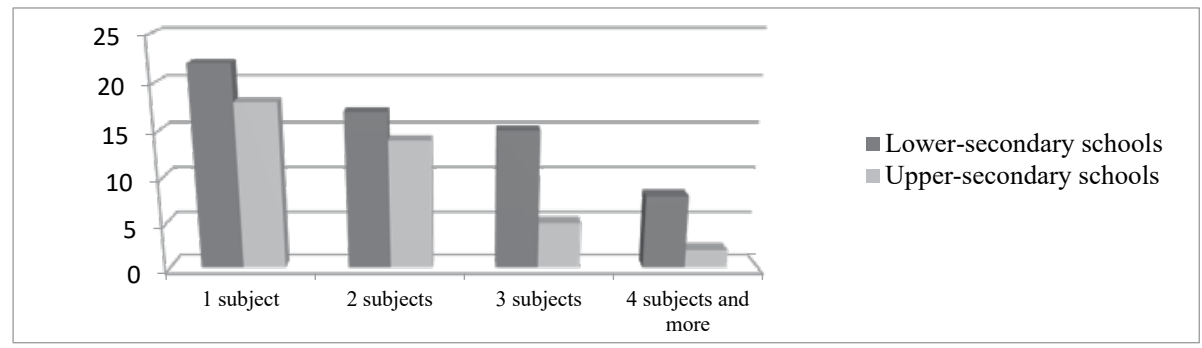

FIGURE 1. Intensity of CLIL provision.

On the basis of the conducted study, the following findings were collected. Out of 62 surveyed lower-secondary schools, there were 22 where one subject was taught every year, 17 schools where the instruction in a foreign language was offered in two subjects, 15 schools with three subjects and eight schools with four or more subjects provided concurrently. With regard to the 39 upper-secondary schools, the following data was collected: 18 schools with one subject, 14 schools with two subjects, five schools with three subjects and three schools with four subjects.

Seven content subjects are investigated in the present study. The results are presented as two circles: the inner circle represents the results for lower-secondary schools, whereas the outer circle shows those for upper-secondary schools. In addition, it seems that the most widely instructed content in lower secondary schools comes from maths, physics, geography, chemistry, history of art and philosophy. Biology is not represented in this type of schooling. On the other hand, the structure slightly differs for upper-secondary schools. While maths and physics still prevail, chemistry is the third most popular subject, in contrast to the findings for lower-secondary schools, Biology is also taught through the medium of a foreign language in upper-secondary schools. Geography and philosophy are the least represented, while history of art is not taught at all.

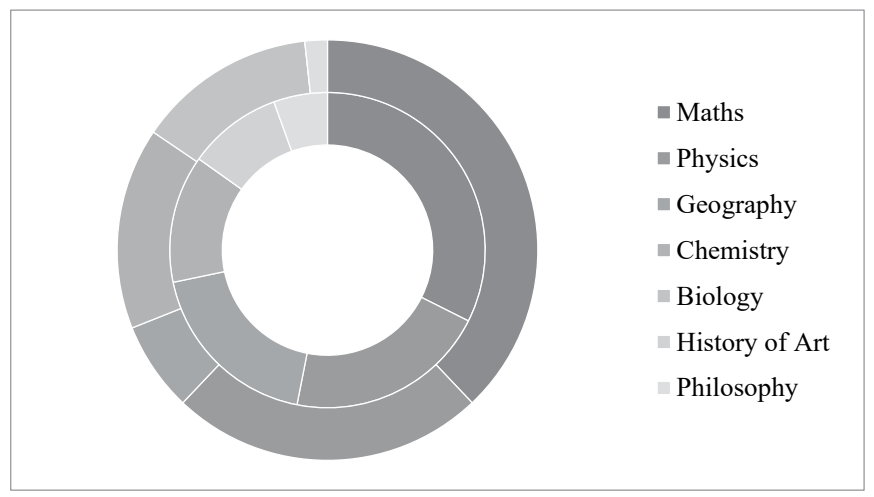

Figure 2. Popularity of subjects taught by each type of school. 


\subsection{The Languages as Medium of Instruction}

As indicated earlier, the most popular language of instruction is English, and the results of the study seem to confirm this trend. The dominance and ubiquity of English as the language of instruction in bilingual teaching has been widely observed in Poland. There is no denying the importance of English as a common means of communication across the world, or its strength as the first foreign language of choice for most non-Anglophone countries in Europe and outside. Hence, most of the students involved in bilingual programmes in Polish lowerand upper-secondary schools are exposed to English, because they undoubtedly perceive its superiority over other foreign languages (Romanowski 2016b).

English is the language used in bilingual provision in 54 out of 62 lower-secondary schools and 31 out of 39 upper-secondary schools. German is obviously the second most popular language, at 26 of the lower-secondary and 10 of the upper-secondary schools surveyed. French is present in 13 lower-secondary schools, and Spanish in only 10 of them. The balance is different in the case of upper-secondary schools, where Spanish is present in nine schools whereas French in only seven of them. Italian is used in only one upper-secondary school, whereas instruction is not offered in this language at the level of lower-secondary education. Russian is not used at any of the school examined in this study. The results demonstrate that in the 101 schools where the study was conducted two or three languages were offered as the medium of instruction at the same time.

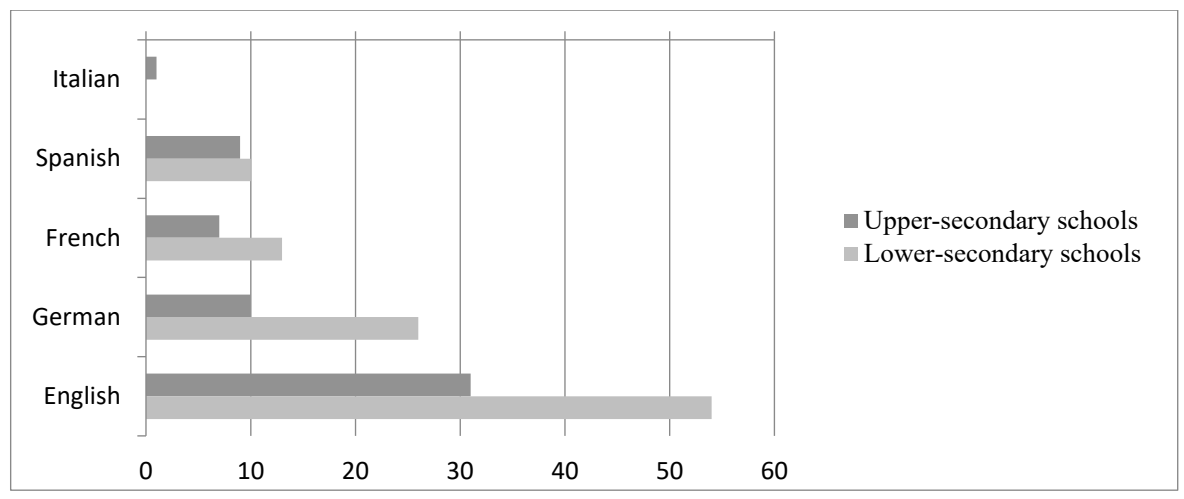

FigURE 3: Languages as medium of instruction by each type of school.

\subsection{Curricular Models as Applied by the Surveyed Teachers}

To understand the complex phenomenon of CLIL provision in Polish secondary schools, it seems essential to analyse the ubiquity of the four curricular models as applied by the teachers involved in the present study. This will also shed some light on the teachers' linguistic competence and their familiarity with the methodology used. As seen in the results outlined below, there is a certain discrepancy between the teachers' overall competence and familiarity with the methodology when comparing the findings in both types of schools, lower- and upper-secondary.

First of all, in Model A, referred to as Extensive Language Medium Instruction, on average 90\% of the lesson time is devoted to studying in a foreign language. The mother tongue is limited to 
those moments where translation of terminology is necessary or short recapitulation of the main points is needed. Hence, according to the collected data, Model A is the most frequently used one. Altogether 87 teachers of lower-secondary schools and 44 teachers of upper-secondary schools admitted using it. The majority of teachers using Model A instruct in English - 50 in lower-secondary schools and 21 in upper-secondary schools - which represents $34.9 \%$ of all the surveyed teachers and $54.2 \%$ of all the English teachers participating in the study. For German there are 28 teachers of lower-secondary schools and 10 teachers of upper-secondary schools using Model A, which constitutes $18.8 \%$ of all the questioned teachers and $63.3 \%$ of all the teachers of German. With French the tendency is similar, as five teachers of lower-secondary schools and seven teachers of upper-secondary schools stated that they used this model. This accounts for $5.9 \%$ of all the teachers and $54.5 \%$ of all the surveyed teachers of French. Out of 10 lower-secondary school teachers of Spanish and seven upper-secondary school teachers, four and five respectively answered that they devoted $90 \%$ of their lesson time to Spanish, accounting for $4 \%$ of all the surveyed teachers and $52.9 \%$ of all the teachers of Spanish. In this study Italian was present in only one school, where the surveyed teacher claimed to be applying Model A (less than $0.5 \%$ of all the teachers and $100 \%$ of all the teachers of Italian).

Model B, Partial Language Medium Instruction, allows for about $50 \%$ of lesson time to be devoted to a foreign language, and thus two languages mingle whenever necessary. In the study 28 teachers of lower-secondary schools and 10 teachers of upper-secondary schools claimed to have used the model successfully. As far as English as the medium of instruction is concerned, 14 teachers of lower-secondary schools and three teachers of upper-secondary stated that they used it, which accounts for $8.3 \%$ of all the surveyed teachers and $16.5 \%$ of all the teachers of English. There are altogether 13 teachers of German (10 teachers in lowersecondary and three teachers in upper-secondary schools) using Model B. This comes to $6.4 \%$ of all the surveyed teachers and $21.7 \%$ of all the teachers of German. For French, only two teachers in lower-secondary and another two in upper-secondary schools said they used Model B in their lessons (1.9\% of all the surveyed teachers and $18.2 \%$ of all the teachers of French). Much the same situation is observed in the case of Spanish, with two teachers in lower-secondary and two teachers in upper-secondary schools, accounting for $1.9 \%$ of all the surveyed teachers and $23.5 \%$ of all the teachers of Spanish.

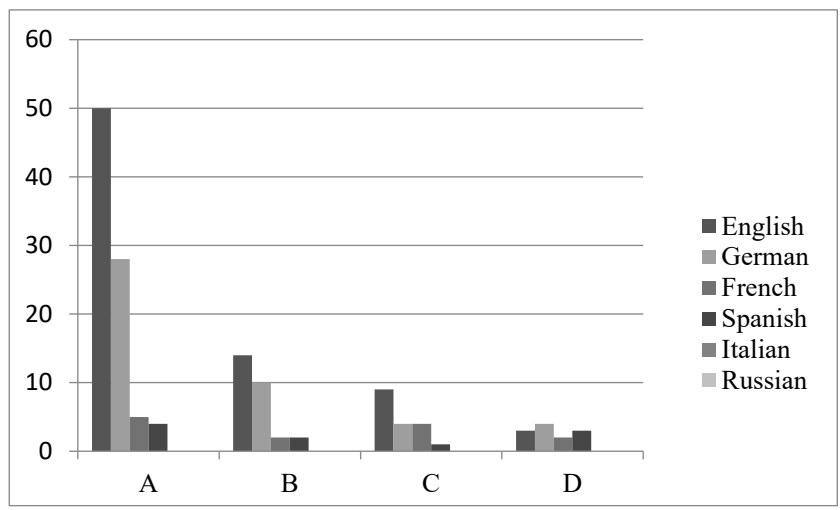

FIGURE 4: Curricular models as distributed by language in lower-secondary schools. 
Limited Language Medium Instruction (Model C) offers lessons with restricted use of a foreign language, for only between $10 \%$ and $50 \%$ of the lesson time. Eighteen teachers out of those surveyed in lower-secondary schools and only four in upper-secondary schools stated that they used this particular model in their everyday teaching. With regard to Model C, English is represented by nine teachers in lower-secondary schools and three teachers in upper-secondary schools. This accounts for $5.9 \%$ of all the surveyed teachers and $11.6 \%$ of all the teachers of English. Only five teachers of German apply Model C (four in lower-secondary and one in upper-secondary schools) - this signifies $2.4 \%$ of all the participating teachers and $8.3 \%$ of all the teachers of German. As for French, it must be noted that Model C is present only in lower-secondary schools, where four teachers stated that it was used in everyday teaching (this accounts for $1.9 \%$ of all the surveyed teachers and $18.2 \%$ of all the teachers of French). With regard to Spanish a similar trend can be observed, as Model C is not used in upper-secondary schools at all and only one teacher in lower-secondary schools claimed to be using it $(0.5 \%$ of all the questioned teachers and $5.9 \%$ of all the teachers of Spanish).

Last but not least, it is Model D - Specific Language Medium Instruction - where little time is offered to students in the selected foreign language. Its use is limited to project work, while most of the content is studied in Polish. This model does not seem to be popular. According to the answers made by the teachers from upper-secondary schools, it is not used at all there. Hence, the presented numbers will only refer to the findings from lower-secondary schools. Only three teachers of English said that they used it $1.5 \%$ of all the teachers and 3\% of all the teachers of English), along with four teachers of German (almost $2 \%$ of all the teachers and $6.7 \%$ of all the teachers of German). In the case of French, only two teachers used Model D (less than 1\% of all the teachers and $9.1 \%$ of all the teachers of French), while only three teachers of Spanish applied it $(1.5 \%$ of all the teachers and $17.7 \%$ of all the teachers of Spanish).

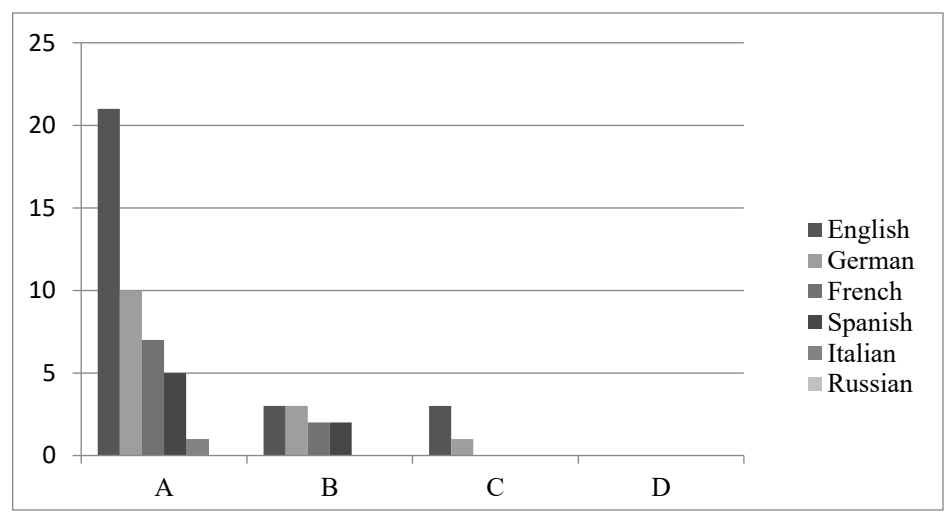

FiguRE 5: Curricular models as distributed by language in upper-secondary schools.

The noted earlier, CLIL curricular models affect the development of students' linguistic competence in the target language. Models A and B, where exposure to L2 is high, increase the students' competence. In other cases, where the focus of the lesson is on the content and the language serves as a tool for instruction (Models C and D), the development of language 
skills will be much slower (Romanowski 2018b). The results to be achieved, depending on the assumed objectives as well as a teacher's qualifications for teaching in bilingual classrooms, vary accordingly. In Poland, in order to be eligible for teaching in CLIL classes, teachers are required to have obtained double qualifications: in both a content subject and a certificate of proficiency in a foreign language (Regulation of the Ministry of National Education 2017). Following this line of reasoning it might be assumed that the choice of curricular model is contingent upon the level of competence a teacher has. Those teachers who are less proficient in a foreign language - the one employed as the language of instruction - are more likely to focus on the content itself as they might have majored from a programme reflecting the taught subjects, i.e. biology, geography, maths, etc. In contrast, teachers who have obtained full qualifications in a foreign language will move the balance towards developing learners' language competence to a very high level (Romanowski 2018b).

It should also be noted that based on the results of the survey, more than a half of the teachers (131 teachers out of 203) said they used Model A, which would signify their high competence in a foreign language. In addition, the teachers in upper-secondary schools seem to have developed greater linguistic preparation for conducting lessons in a foreign language, as they mainly stick to Models A and B. The study also reveals one more interesting finding, which is that the teachers of English most often use Model A. This is because there are more possibilities in terms of the preparation, courses and seminars that are available for teachers of this particular language, along with the wider availability of course books, guidebooks and supplementary materials.

\section{Conclusion}

Bilingual teaching in secondary schools became a necessity in Poland a long time ago, and the majority of schools have realized this type of provision through CLIL, which is also the most common type of methodology that had been adopted successfully in most EU countries. The subjects offered in bilingual provision do not differ much from those in other countries, i.e. Germany and Spain, which can be regarded as pioneers of CLIL (Papaja 2014; Romanowski 2018b).

The results of the study clearly indicate that there is still much to be worked on and improved. The need to unify the curricula and the amount of exposure in a foreign language employed as a medium of instruction would seem the most urgent issues to be resolved. As English is the most commonly used language of instruction prevailing in all secondary education and reaching far beyond it, it would be reasonable and natural to promote German and French in this context, as they are regarded as the procedural languages of the European Commission. The learning of Spanish and Italian, which, as revealed by the study, there is a growing demand for, will hopefully raise the interest of Europeans in mastering lesser known languages and introduce them to system of education in the future. In addition, European citizens need competences in more than one foreign language, so bilingual education may be the only solution for the multilingual EU of the future. As such, we need to pursue the further development of plurilingual competence in bilingual programmes, as envisaged in the Council of Europe documents (Romanowski 2016a). 
Finally, yet importantly, the classroom procedures and strategies employed by the majority of in-service teachers require further elaboration and investigation. The qualifications of those working in bilingual classrooms need to be verified against the existing regulations. Polish teachers involved in bilingual teaching require subsequent training, without which effective teaching will not be possible. Obviously, we can benefit enormously from the experiences of other countries. In the first step, the aim(s) of bilingual education through CLIL should be rigorously defined. It is of the utmost importance to be clear about the expected outcomes of CLIL provision for the Polish students. As a second step it could be possible to point out which non-linguistic disciplines seem to be particularly appropriate for this type of instruction. Every content subject (geography, biology, chemistry, etc.) may give their own contribution to the bilingual aim, even if not every topic is adequate for it.

\section{References}

Anderson, Jim. 2009. "Relevance of CLIL in Developing Pedagogies for Minority Language Teaching." In CLIL Practice: Perspectives from the Field, edited by David Marsh, 124-32. CCN University of Jyväskylä.

Baetens-Beardsmore, Hugo. 1993. European Models of Bilingual Education. Clevedon: Multilingual Matters.

Cenoz, Jasone, and Fred Genesee. 1998. Beyond Bilingualism: Multilingualism and Multilingual Education. Clevedon: Multilingual Matters.

Coyle, Do, Phillip Hood, and David Marsh. 2010. CLIL. Content and Language Integrated Learning, Cambridge: Cambridge University Press.

Czura, Anna, and Katarzyna Papaja. 2013. "Curricular Models of CLIL Education in Poland." International Journal of Bilingual Education and Bilingualism 16 (3): 321-33. https://doi.org/10.1080 /13670050.2013.777388.

Dalton-Puffer, Christiane. 2011. "Content and Language Integrated Learning: From Practice to Principle?" Annual Review of Applied Linguistics 31 (1): 182-204. https://doi.org/10.1017/S0267190511000092.

—. 2017. "Postscriptum: Research Pathways in CLIL/Immersion Instructional Practices and Teacher Development." International Journal of Bilingual Education and Bilingualism 21 (3): 384-87.

Dzięgielewska, Zuzanna. 2002. "Problematyka nauczania języka i przedmiotów niejęzykowych w klasach dwujęzycznych - licea z językiem francuskim." [Problematizing Teaching Language and Non-Language Subjects in Bilingual Classrooms - Secondary Schools with French.] Języki Obce w Szkole 6: 79-82.

—, ed. 2008. Nauczanie dwujezyczne w Polsce i Europie. [Bilingual Education in Poland and Europe.] CODN: Warszawa.

Genesee, Fred. 1987. Learning Through Two Languages: Studies of Immersion and Bilingual Education. Rowley, MA: Newbury House.

Gierlinger, Erwin Maria. 2017. "Teaching CLIL? Yes, but with a Pinch of SALT.” Journal of Immersion and Content-Based Language Education 5 (2): 187-213. https://doi.org/10.1075/jicb.5.2.02gie.

Górowska-Fells, Magdalena. 2012. "Kluczowe dane o nauczaniu języków obcych w Europie.” [Key Data on Teaching Foreign Languages in Europe.] Jezzyki Obce w Szkole 4: 51-56.

Iluk, Jan. 2000. Nauczanie bilingwalne: modele, koncepcje, zatożenia metodyczne. [Bilingual Education: Models, Concepts and Methodological Assumptions.] Katowice: Wydawnictwo Uniwersytetu Śląskiego.

Lo, Yuen Yi, and Ernesto Macaro. 2015. "Getting Used to Content and Language Integrated Learning: What Can Classroom Interaction Reveal?” The Language Learning Journal 43 (3): 239-55. https://doi .org/10.1080/09571736.2015.1053281.

Merino, Jon Ander, and David Lasagabaster. 2015. “CLIL as a Way to Multilingualism.” International Journal of Bilingual Education and Bilingualism 21 (1): 79-92. https://doi.org/10.1080/13670050 .2015 .1128386 .

Maljers, Anne, David Marsh, and Dieter Wolff, eds. 2007. Windows on CLIL. Content and Language Integrated Learning in the European Spotlight. European Platform for Dutch Education. 
Marsh, David, and Dieter Wolff, eds. 2007. Diverse Contexts - Converging Goals. CLIL in Europe. Frankfurt am Main: Peter Lang.

Marsh, David, Marek Zając, and Hanna Gozdawa-Gołębiowska. 2008. Profile Report Bilingual Education (English) in Poland. Overview of Practice in Selected Schools. CODN: British Council Poland and University of Jyväskylä.

Marsh, David, Peter Mehisto, Dieter Wolff, and Maria Jesus Frigols-Martin. 2010. The European Framework for CLIL Teacher Education. Graz: European Centre for Modern Languages (ECML).

Mehisto, Peter, David Marsh, and Maria Jesus Frigols. 2014. Uncovering CLIL. Content and Language Integrated Learning in Bilingual and Multilingual Education. Oxford: Macmillan Education.

Papaja, Katarzyna. 2014. Focus on CLIL. A Qualitative Evaluation of Content and Language Integrated Learning (CLIL) in Secondary Education. Newcastle upon Tyne: Cambridge Scholars.

Pawlak, Mirosław. 2015. Edukacja dwujęzyczna w polskich szkotach. Raport ewaluacyjny." [Bilingual Education in Polish Schools. An Evaluation Report.] Warszawa: Ośrodek Rozwoju Edukacji.

Pérez Cañado, Maria Luisa. 2014. "Teacher Training Needs for Bilingual Education: In-service Teacher Perceptions." International Journal of Bilingual Education and Bilingualism 30 (3): 266-95. https://doi .org/10.1080/13670050.2014.980778.

—. 2016. "Are Teachers Ready for CLIL? Evidence from a European Study." European Journal of Teacher Education 39 (2): 202-21. https://doi.org/10.1080/02619768.2016.1138104.

Regulation of the Ministry of National Education. 2017. Journal of Laws 2017.1575, August 24, 2017.

Romanowski, Piotr. 2016a. "Some Reflections on the Idiosyncrasy Of Bilingual Education in Secondary Schools in Poland." Bilingual Landscape of the Contemporary World, edited by Sambor Grucza, Magdalena Olpińska-Szkiełko and Piotr Romanowski, 173-88. Frankfurt am Main: Peter Lang.

—. 2016b. "A Statistical Analysis of the State of Foreign Language Learning in the EU." Lingwistyka Stosowana/ Applied Linguistics/Angewandte Linguistik 17 (2): 67-79. https://doi.org/10.32612/uw .20804814.2016.2.pp.67-79.

—. 2018a. "CLIL's Role in Facilitating Intercultural Learning." Applied Linguistics Papers 25 (2): 71-87. https://doi.org/10.32612/uw.25449354.2018.2.pp.71-87.

—. 2018b. "CLIL Models in Polish Lower-secondary Schools." Kwartalnik Neofilologiczny 4: 592-605.

Ruiz de Zarobe, Yolanda, ed. 2017. Content and Language Integrated Learning: Language Policy and Pedagogical Practice. London: Routledge.

Wolff, Dieter. 2003. "Content and Language Integrated Learning: A Framework for the Development of Learner Autonomy." In Learner Autonomy in the Foreign Language Classroom: Teacher, Learner, Curriculum and Assessment, edited by David Little, Jennifer Ridley and Emma Ushioda, 211-22. Dublin: Authentik.

Wolff, Dieter, and Agnieszka Otwinowska-Kasztelanic. 2010. "CLIL - przełomowe podejście w edukacji europejskiej." [CLIL - A Breakthrough Approach in European Education.] Jezzyki Obce w Szkole 6: 7-13.

Zielonka, Bronisława 2007. “CLIL in Poland.” In Windows on CLIL. Content and Language Integrated Learning in the European Spotlight, edited by Anne Maljers, David Marsh and Dieter Wolff, 147-53. European Platform for Dutch Education. 